\title{
Patient-Centered Care: Transforming the Health Care System in Vietnam With Support of Digital Health Technology
}

Thu Ha Dang ${ }^{1,2,3}$, MD, MIPH; Tuan Anh Nguyen ${ }^{1,4,5,6}$, BPharm, MPharm, PhD; Minh Hoang Van ${ }^{7,8}$, MD, MPH, PhD; Olinda Santin ${ }^{9}, \mathrm{PhD}$; Oanh Mai Thi Tran ${ }^{6}, \mathrm{MD}, \mathrm{PhD}$; Penelope Schofield ${ }^{2,10,11}$, BSc (Hons), PhD

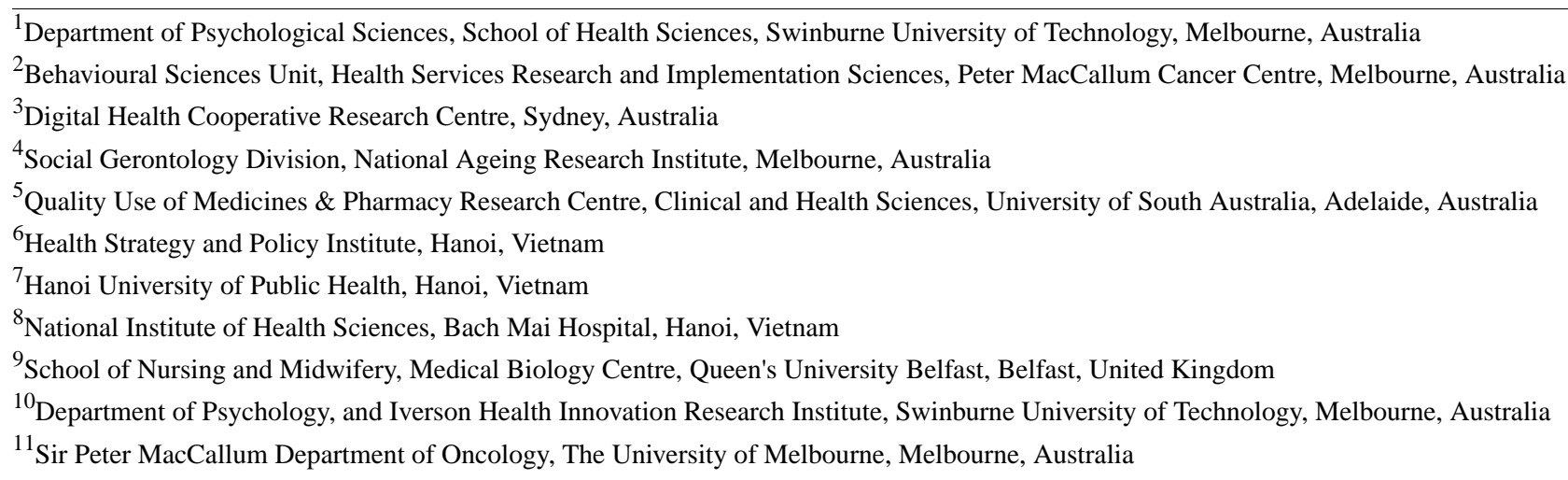

\section{Corresponding Author:}

Thu Ha Dang, MD, MIPH

Department of Psychological Sciences

School of Health Sciences

Swinburne University of Technology

John Street

Hawthorn

Melbourne, 3122

Australia

Phone: 61422703347

Email: thuhadang@swin.edu.au

\begin{abstract}
Background: Over the recent decades, Vietnam has attained remarkable achievements in all areas of health care. However, shortcomings including health disparities persist particularly with a rapidly aging population. This has resulted in a shift in the disease burden from communicable to noncommunicable diseases such as dementia, cancer, and diabetes. These medical conditions require long-term care, which causes an accelerating crisis for the health sector and society. The current health care system in Vietnam is unlikely to cope with these challenges.
\end{abstract}

Objective: The aim of this paper was to explore the opportunities, challenges, and necessary conditions for Vietnam in transforming toward a patient-centered care model to produce better health for people and reduce health care costs.

Methods: We examine the applicability of a personalized and integrated Bespoke Health Care System (BHS) for Vietnam using a strength, weakness, opportunity, and threat analysis and examining the successes or failures of digital health care innovations in Vietnam. We then make suggestions for successful adoption of the BHS model in Vietnam.

Results: The BHS model of patient-centered care empowers patients to become active participants in their own health care. Vietnam's current policy, social, technological, and economic environment favors the transition of its health care system toward the BHS model. Nevertheless, the country is in an early stage of health care digitalization. The legal and regulatory system to protect patient privacy and information security is still lacking. The readiness to implement electronic medical records, a core element of the BHS, varies across health providers and clinical practices. The scarcity of empirical evidence and evaluation regarding the effectiveness and sustainability of digital health initiatives is an obstacle to the Vietnamese government in policymaking, development, and implementation of health care digitalization.

Conclusions: Implementing a personalized and integrated health care system may help Vietnam to address health care needs, reduce pressure on the health care system and society, improve health care delivery, and promote health equity. However, in 
order to adopt the patient-centered care system and digitalized health care, a whole-system approach in transformation and operation with a co-design in the whole span of a digital health initiative developing process are necessary.

(J Med Internet Res 2021;23(6):e24601) doi: 10.2196/24601

\section{KEYWORDS}

building blocks; digital health; eHealth; patient-centered care; telemedicine; Vietnam

\section{Introduction}

\section{Overview}

Following broad economic reforms known as Doi Moi in 1986, Vietnam has attained remarkable health care improvement, reflected in core health indicators [1]. From 1988 to 2018, life expectancy at birth increased from 69.9 years to 75.3 years, under-5 mortality rate decreased from $56 \%$ o to $20.7 \%$, and infant mortality reduced from $39.6 \%$ to $16.5 \%$ [2]. Health care expenditure gradually increased and was forecasted to triple from US \$15.6 billion in 2018 to US \$42.9 billion in 2028 [3]. Despite these improvements, the health care system still faces significant challenges including wide disparities in health and growing health care costs. The disparities in core health indicators are particularly observed between urban and rural residents, across different regions, and among population groups [4]. For example, the maternal mortality ratio and infant mortality rate in some mountainous areas are 3 to 4 times higher than those in lowland and urban areas and almost double the national average rates [4].

Vietnam is undergoing a dramatic demographic transition resulting in an aging population. The number of people aged 65 years and over is estimated to increase from $10 \%$ of the population in 2015 to $28 \%$ in 2050 [5]. The combination of an aging population, increased industrialization, and changes in population lifestyle have created a double disease burden, with a shift from communicable to noncommunicable diseases (NCDs). Specifically, the mortality rate caused by NCDs rose from $45.5 \%$ in 2010 to $77 \%$ in 2016 and is projected to climb $[3,4,6]$. The double disease burden means that Vietnam is facing more costly health conditions such as dementia, cancer, and multimorbidity. In addition to this, the country still faces significant burden of infectious conditions and a number of new epidemics such as COVID-19. These health challenges must be addressed using a systemic approach by the whole government of Vietnam to improve health for its population.

To improve health care problems and the health status of the population, there is a critical need for a well-functioning health care system that can deliver services equitably and efficiently [7]. The World Health Organization (WHO) developed an evidence-based building blocks framework as a tool to help its member states analyze their health care systems. This framework allows nations to consider the multifaceted nature of their health systems and interdisciplinary and multilevel responsibility in health care [7]. The WHO framework assesses health systems using 6 core components or building blocks. Each building block and its indicators were initiated by a group of agency representatives and technical experts, shared broadly with country experts, and followed by evaluations through a series of case studies and reviews of country experiences [7]. These components focus on the key chains of the monitoring and evaluation framework developed by the International Health Partnership, namely inputs, processes, and outputs [8]. The relation between the 6 building blocks and this monitoring and evaluation framework is summarized in Figure 1. In the following section, the 6 building blocks and corresponding indicators are used to describe Vietnam's health care system, comprising financing and health workforce components (inputs and processes), medical products, technologies, and service delivery components (immediate outputs), and cross-cutting components: leadership/governance and health information systems [7].

Figure 1. Health system strengthening: relationship between the World Health Organization building blocks (6 core components, top) and International Health Partnership monitoring and evaluation framework (inputs, processes and outputs, bottom).

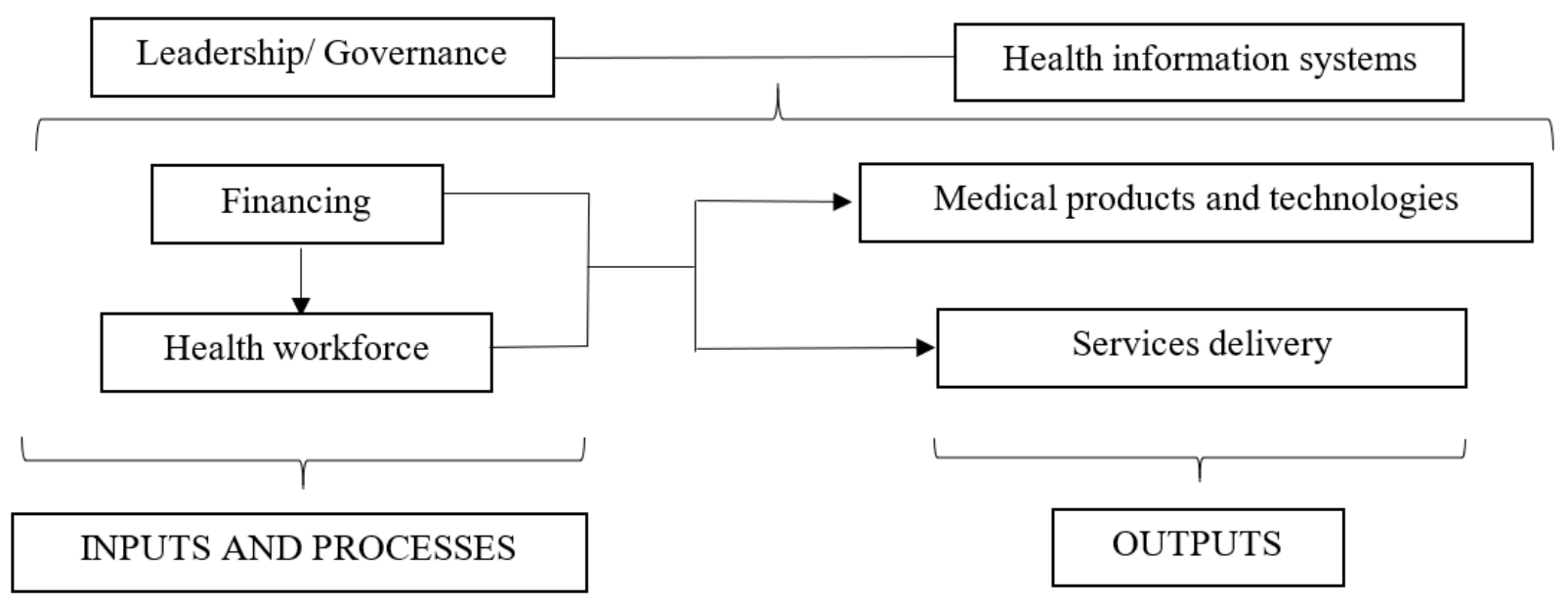




\section{Health Care System in Vietnam}

\section{Health Financing}

Health financing is a key building block in a national health system, largely influencing the inputs, thus affecting the availability, affordability, and accessibility of health services. A good health financing system should move toward universal health coverage, where all people have access to needed health services without financial hardship. This could be achieved through increasing total health expenditure (THE) and decreasing the proportion of households facing financial catastrophe as a result of out-of-pocket payments (OPP) [7].

With multiple health financing reforms, Vietnam's THE per capita increased from US \$14 in 1995 to US \$113 in 2014 $[9,10]$, thus within the internationally defined range and enough for universal coverage of key health interventions [7]. The increase in public health expenditure (mainly comprising state budget [11] and social health insurance [12]) has increased health care coverage for some groups including the poor, ethnic minorities, under-6-year-old children, over-80-year-old people, and socially vulnerable groups through the government's subsidized schemes [13]. However, patient OPP remained high, accounting for $40.8 \%$ of THE in 2015, which was higher than that of other countries in the Asia Pacific region and the WHO recommended level $[10,11]$. The high OPP led to catastrophic expenditure and pushed many Vietnamese families into poverty, resulting in health care inequity [14,15]. The current model of the health care system and financing needs further reforms to address a surge in health care expenditure caused by the aging population and shifting disease pattern in Vietnam.

\section{Health Workforce}

The health workforce is another key building block to provide inputs and processes to the monitoring and evaluation chain of health systems. The ability of a country to meet its health goals largely depends on people in charge of organizing and delivering health services. Evidence of the direct and positive link between numbers of health workers and population health outcomes has been demonstrated in several studies $[16,17]$.

The health workforce in Vietnam has gradually improved in both quantity and quality. The number of doctors and pharmacists increased from 7.2 and 1.76 per 10,000 people in 2010 to 8.0 and 2.2 per 10,000 people in 2015 , respectively [4]. In $2015,65 \%$ to $95 \%$ of the health facilities and about $90 \%$ of the health workers in hospitals at central and provincial levels were licensed [4]. Despite this significant improvement, Vietnam's health workforce was still insufficient to meet staffing norms and clinical needs [4] and inappropriately distributed across regions and levels/areas of care. The aging population and shifting disease burden to those requiring long-term care for chronic NCDs are likely to lead to severe shortages in health resources, which occur in highly specialized fields such as cancer, palliative care, and mental health and in hard-to-reach areas such as North West, Central highlands, and Mekong Delta regions [4,18-20]. The mountainous and remote areas lack not only specialists trained in advanced diagnostic and treatment approaches but also standard medical and diagnostic equipment, which diminishes the quality of health care services in these areas compared to urban regions [4]. This wide disparity in health care between the rich and the poor, urban and rural, is demonstrated in the disparity of core health indicators such as life expectancy at birth and infant and under-5 mortality rates [4].

Overcrowding in health facilities, especially in urban and specialized hospitals, is a main cause of health worker exhaustion. Nearly one-fifth of Vietnamese clinical nurses experienced burnout and occupational stress [21]. Clinician burnout directly reduces the quality of life of clinicians and adversely affects the quality of care to patients. It also indirectly contributes to the reduction of health staffing [22]. Hence, a vicious negative cycle for Vietnam's health sector is created.

\section{Health Service Delivery}

Health service delivery is reflected in the availability and readiness of services across the health care continuum. Vietnam has achieved significant service improvement in health care: for example, the ratio of hospital beds per 10,000 people increased from 21.5 in 2011 to 24.0 in 2015 [4]. The hospital quality management system was established in 2013 and available in $55.4 \%$ of hospitals throughout the country in 2015 [23].

Service provision is immediate outputs of the inputs into the health system such as financing, workforce, procurement, and supplies [7]. It will be difficult to achieve the outputs if the inputs are insufficient. Even if the inputs are adequate, whether the outputs are obtained depends very much on the efficiency of the health system's functioning. According to Bentley et al [24], there are 4 key inefficiencies: duplication of services, inefficient processes, overly expensive inputs, and medical errors. All of these forms of inefficiency occur in Vietnam's health sector.

Vietnamese patients' laboratory tests and results are not usually archived at medical facilities or shared between different health care providers. This poses a challenge as patients experience multiple visits to doctors and specialists for the same health conditions thus leading to duplication of services [3]. Public hospitals, especially in large cities, are usually overcrowded with 2 to 3 patients sharing a bed. Limited quality of health care services at the commune level leads to reduced patient trust in primary care. Also, if patients use OPP, the health care system allows them to easily bypass lower level facilities (eg, commune health stations) and seek health care services in leading tertiary hospitals in big cities without referrals (ie, inefficient processes), even just to treat common diseases that primary care is well equipped to manage (ie, overly expensive inputs) [4,25]. Consequently, higher level hospitals are drained of resources, while there is waste at lower levels due to underuse [26]. Overcrowding in high-level health facilities is associated with medication errors. A large prospective study in two urban hospitals in Vietnam revealed that medication errors occurred in more than one-third of all medication doses [27].

There are also discrepancies in health service readiness and quality across areas of health care. Vietnam has an extensive primary health care system that reaches almost every administrative jurisdiction and acts as the main entry point to 
public health care. However, grassroots level facilities have inadequate infrastructure required for basic health care delivery. For example, only $76 \%$ of commune health stations in Dien Bien province (a Northern mountainous province) have a source of clean water, and a significant number of district hospitals lack essential equipment such as child ventilators and electrocardiograms [28]. Also, there have been increasing concerns about the equity and quality of basic health service provisions in primary health care. These limitations were reflected in key health indicators, with the infant mortality rate among the ethnic minority population being over 4 times higher than that of Kinh and Hoa ethnic groups, who mostly live in urban areas [28].

\section{Access to Essential Medicines}

According to WHO, a well-functioning health system should be able to provide the population it serves with equitable and affordable access to essential medicines, medical products, and technologies and use this resource efficiently [7]. However, published literature consistently reported that medicine prices in Vietnam were high and unaffordable for many Vietnamese people [29-31]. A fragmented medical information system within and between health care and other sectors such as General Department of Vietnam Customs and Ministry of Finance, as well as a shortage of personnel and resources for enforcing medicine pricing policies was one of the reasons for their high price in Vietnam [32]. Because of high medicine prices, irrational selection and use of medicines, unsustainable pharmaceutical production and distribution systems, and a lack of financial support systems for medicine procurement, access to the right medicines at the times people need them remains a major challenge for the majority of the Vietnamese people [33-37].

\section{Health Information}

The health information system (HIS) is a crosscutting building block because it creates a foundation for all decision-making processes in a health system. Vietnam has achieved significant progress in this area. A number of health statistics are generated annually: for example, the Annual Health Statistic Yearbook, Joint Annual Health Review, and Statistical Yearbook. Information technology is applied widely in the health administration and management of all 63 provinces and cities across the country. Vietnam is also strongly promoting the development of a health management database for its over 90 million citizens [4].

Vietnam's HIS, however, still faces a number of issues and challenges, including data generation, validation, and uses. For example, data from health care facilities, especially from private and industrial sectors, are neither timely nor complete. Information from local death registration is incompatible with WHO recommendations. There are discrepancies in the quality of medical records across regions and levels of care, which creates challenges for continuing health monitoring, disease prevention and treatment, and management of medical errors and adverse drug reactions. Even after the data are collected, the unclear data dissemination mechanism in Vietnam will likely restrict data use [4]. Given the importance of this crosscutting building block of the health system, reform is needed to operate
HIS more effectively, especially in the new era of information technology.

\section{Leadership and Governance}

Health leadership and governance is another crosscutting building block in a health care system. It mediates other building blocks by connecting all issues surrounding the accountability of various stakeholders in the system to ensure adequate resources (finance, workforce, medical supplies, and information) are available to deliver essential health services. In terms of health care governance, Vietnam has attained remarkable progress, demonstrated in the development of a strong policy framework in health care. The enactment of important laws and policies, such as health insurance and pharmacy laws [38,39], and the Health Sector Strategy for 2011-2020 with a Vision to 2030 [40] provided a solid foundation and led to the formation of regulations, guidelines, initiatives, and plans in these areas. The organizational structure of Vietnam's health system has been adjusting to meet health care needs at various levels, such as establishing information technology administration at central levels and formally affirming the function and tasks of community health services at local levels [4]. Nevertheless, health policies in Vietnam are sometimes overlap, inconsistent and lack evidence. Lack of detailed plans and information cause difficulty for the effective implementation of policies. Additionally, insufficient sanctions and a weak inspection network for policy enforcement are also shortcomings of Vietnam's health care governance [4]

In summary, Vietnam has attained significant achievement and improvement in all 6 areas of the health system framework. However, shortcomings persist. To address all these systemic challenges and achieve optimal and equitable health outcomes for the population, the Vietnamese government must consider adapting the current model of health care operation to meet rapidly changing population trends, patterns of disease, and health care needs and use existing resources more efficiently while improving health infrastructure. The application of digital health technologies to underpin the health care system transformation is critical to success [41]. "The use and scale-up of digital health solutions can revolutionize how people worldwide achieve higher standards of health and access services to promote and protect their health and well-being" [42]. As in many other countries, Vietnam's health care system will need to be migrated to the patient-centered care model, which focuses on patients and their particular health care needs, and patients will need to be empowered to become active participants in their care to optimize health and economic outcomes [43]. This study was conducted to explore the opportunities, challenges, and necessary conditions for Vietnam in transforming toward a patient-centered care model to produce better health for people and reduce health care costs.

\section{Methods}

\section{Approach}

In this paper, we explored a Bespoke Health Care System (BHS) developed by Schofield et al [44] as an ideal example of a comprehensive patient-centric care model. The current Vietnamese digital health and health care landscape was 
examined using a strength, weakness, opportunity, and threat (SWOT) analysis to argue for the potential of developing a BHS in Vietnam. We then discuss necessary and sufficient conditions and challenges for Vietnam in transforming toward this patient-centered care model to produce better health for people and reduce health care costs.

\section{Bespoke Health Care System}

In 2019, Schofield et al [44] first introduced the concept of the BHS in the context of Australian health care, which has been adapted to other contexts $[45,46]$. The development of the BHS was based on the pedagogical model of flipping the classroom in modern education [47] and its application in health care [48]. In Australia, this approach has been applied by many health professionals [47]. Patients were equipped with necessary knowledge before consultations. Therefore, the consultation time was effectively used to solve health problems and make joint decisions [47]. The core component of the BHS is "increasing patient involvement in health care decisions and self-management assisted by the use of technology" [49]. In this model, patients will be educated about their illness and management options, flipping their role from passengers to drivers to manage their own health care, with clinicians playing more of a support role being the "guide by the side." Although the BHS was proposed as an ideal comprehensive patient-centric care system with several advantages and benefits, there is no one-size-fits-all approach. Novel health care solutions will work best when they are adapted to suit a country's specific conditions and have broad-based acceptance among the community, health care providers, and government agencies.

\section{SWOT Analysis}

The SWOT analysis has been used widely in policy research to provide policy makers with a sound basis for strategy development and formulation and identify new avenues for national health care reform [50]. The technique examines 4 parameters: strengths, weaknesses, opportunities, and threats. In this paper, strengths and weaknesses refer to internal factors of the proposed BHS that place it at an advantage or disadvantage over the current Vietnamese health care system, respectively. Opportunities and threats refer to external factors to the BHS that support or prevent it from being adopted in Vietnam.

\section{Results}

\section{Strengths}

The BHS brings a number of potential benefits to a health care system. First, the BHS proposes integrating electronic medical records (EMRs) into a patient-centered management platform. Currently, EMRs act as passive information depositories mainly for the purposes of health data storage or analysis. In the proposed BHS, every person would have their EMR containing all relevant personal and medical information that is shared across health care providers. As such, relevant health workers and agencies would have access to patients' real-time health information, saving time in managing people's health, saving costs of unnecessary or duplicated examinations and laboratory tests, and reducing medication errors. Studies have revealed that one-fifth of medical errors were due to insufficient patient medication information [48,51]. Clinical access to patients' real-time health information would enable tailored precision and holistic health solutions for individuals.

Second, the BHS proposes that the EMR is an active tool in promoting optimal health management. The proposed platform would remotely track symptoms, prompt patients to perform routine screening tests, allow patients to book medical appointments and remind them to attend, and provide scheduled reminders for adherence to medical recommendations. Electronic prompts and reminder alerts have been shown to assist individuals in adhering to clinical intervention effectively, particularly in managing long-term chronic conditions [49].

Third, the BHS serves as an education platform, upskilling patients and health workers. In the BHS, patients would optimally be equipped with a comprehensive understanding of their conditions, treatment options, and self-management strategies. This is an effective way to empower people to have greater ownership in managing their health. Additionally, clinicians would be provided with up-to-date, evidence-based optimal health care pathways suitable for their specific patients' conditions. This offers an ongoing mechanism to support clinicians' continuing professional development using their own case studies. Moreover, the platform might be used to upskill patient families and carers, which would strengthen community care and lessen the health care burden due to staff shortages [51]. Potentially, the BHS would facilitate reducing the health inequities in terms of accessing optimal health care, particularly for the economically disadvantaged or those living in remote areas.

In summary, adopting the BHS model may assist Vietnam in addressing the health crisis and achieving the country's health care goals in the new decade. This model can increase patient accessibility to health care facilities and state-of-the-art health management, including the most vulnerable and hard-to-reach people, thus enhancing health equity across the country. It can also increase operational efficiencies for both health care providers and users, resulting in lessening overcrowded hospitals and enabling coordinated health care, which is currently missing [3,52]. Moreover, digital solutions can assist teaching, tertiary, or specialized hospitals to deliver training or conduct eHealth consultations with satellite, primary, or secondary hospitals. Therefore, the quality of health care would be strengthened across the country.

\section{Weaknesses}

Although the BHS model has many strengths, we need to articulate inherent weaknesses in the model. First, the high cost and complexity of implementing digital health information systems, such as EMRs, may be a barrier to broad dissemination. Second, the digitalization of data and services represents a potential cybersecurity threat to privacy and trust of people in a new health care system [3]. Finally, the establishment of nationwide unique health IDs (unique codes used to identify individuals within the health care system) often takes time, especially for socially disadvantaged members of the community. 


\section{Opportunities}

Vietnam has a high-level policy framework (ie, political and legal environment) supporting the transition toward the BHS. The 2017 Resolution 20-NQ/TW of the Communist Party of Vietnam has provided a strategic orientation for reforming the health care system. This includes systemic implementation of information technology in management of primary health care, prevention, disease management, and the establishment of electronic health records (EHRs) for all citizens that link to their health insurance card.

Based on this strategic orientation, the Vietnamese Ministry of Health (MOH) in 2017 set out national goals for the protection, care, and improvement of people's health in the period to 2030. One of the 5 key priorities for action to achieve the national health care goals was developing human resources, medical sciences, and technology [4,53]. Since then, a national agenda for digitalization of the health care system has been driven by $\mathrm{MOH}$ with a number of initiatives that aim to adopt digital solutions in health care network across the country. Vietnam is rapidly embracing digital health. Digitalized health care is perceived as a useful solution that could help to address the rapidly growing gap between service demand and capacity [44].

To implement health care digitalization, $\mathrm{MOH}$ issued Circular 54/2017/TT-BYT regarding assessment criteria for information technology applications in health care facilities [50] and a plan to develop smart health care during the period 2018-2025, with a vision toward 2030 [54]. In this plan, targeted smart health outcomes were specified, such as development of a national health care data center, electronic health and medical records, and electronic government and smart medicine management systems. Particularly in the field of examination and treatment, telemedicine is regulated by Circular 49/2017/TT-BYT, which provides guidelines for a range of telemedicine consultations in Vietnam (eg, allowing doctors to provide telemedicine services to patients under certain infrastructure requirements [55]).

To accelerate the application of information technology in the health sector, in 2018, MOH issued Circular 46/2018/TT-BYT regulating EMRs. According to Häyrinen et al [56], EMR was defined as "a repository of patient data in digital form, stored and exchanged securely, and accessible by multiple authorized users. It contains retrospective, concurrent, and prospective information, and its primary purpose is to support continuing, efficient, and quality integrated health care." In the circular, EMRs include inpatient records, outpatient records, and other medical records prescribed by $\mathrm{MOH}$, such as traditional medicine medical records and medical records of abortion. This is the first time Vietnam has specific guidance for EMR establishment, use, and management at health care facilities [57]. As the health care system in Vietnam is centralized under $\mathrm{MOH}$ and provincial health authorities, the integration of EMRs within the existing system, at least in the 47 central-level hospitals and possibly also at 419 provincial-level hospitals [58], will be easier than in countries with a more fragmented health care system.

The plan for implementing EHRs was approved by $\mathrm{MOH}$ in 2019 in Decision 5349/QĐ-BYT [59]. According to this decision, EHRs are medical documents that record the health care process of a person from birth to death in the form prescribed by $\mathrm{MOH}$. This plan guides and directs all 61 cities and provinces of Vietnam to simultaneously deploy and make EHRs available for use by $80 \%$ and $95 \%$ of population in 2020 and 2025, respectively. If this aim is achieved, Vietnam will be perfectly positioned to adapt and adopt the BHS model. EHRs may be able to assist every citizen to understand and manage their health information continuously for life, enabling them to prevent disease proactively, and actively manage their health conditions if used as the basis for a BHS. EHRs will also support physicians in providing health care for people in real time and according to best practice health care recommendations. Importantly, EHRs will provide complete, accurate, and timely data on population health, enabling policy makers to advance evidence-based health policy and health authorities to examine the relative efficacy of treatments to manage health care expenditure more efficiently.

Supportive social and technological environments also place Vietnam in a good position to adopt advanced digital health solutions of the BHS. Today, Vietnam is benefiting from a golden population proportion with $70 \%$ of the population being of working age (aged 18 to 65 years) [6]. This generation is rapidly embracing new communication technologies. In 2020, Vietnam was the seventh highest number of Facebook users in the world [60]. On average, Vietnamese people spend about 7 hours per day on the internet [61]. The high uptake is associated with a high acceptability of digital technologies by Vietnamese people. Studies have shown that people's attitudes toward mobile health solutions is highly positive. Two-thirds of Vietnamese youth and adolescents found mobile health apps useful $[62,63]$.

Online communication is backed by a rapid and strong development of the country's information and communication technology infrastructure: penetration rate of internet access is $67 \%$, which is among the highest in the Asia Pacific region [64], and $95 \%$ of households are now able to use $4 \mathrm{G}$ network [3]. Vietnam's technology infrastructure is also embracing cloud-based services, which will facilitate innovative and cost-effective health care delivery solutions. In recent years, a number of projects have initiated and implemented digital health services in large urban hospitals, including teleradiology, teleconsultation, telediagnosis, and videoconferencing. Examples of these initiatives include raising disease awareness and encouraging people to adopt heathier behaviors [65-69], improving accessibility to health care services among disadvantaged and vulnerable target groups [70-72], and upskilling health care workers [73-80].

A supportive economic environment has resulted in an increased need for high-quality health care services and precision medicine. Strong economic growth with an average annual gross domestic product growth rate of $6.4 \%$ [81] is creating a booming middle class in the society. It is estimated that this population will increase sharply from $10 \%$ in 2015 to more than $50 \%$ in 2035 [82]. The growth in disposable income among digitally literate, educated, and wealthy individuals creates economic conditions for higher personal expenditure on easily accessible, high-quality health care. Public health facilities often do not 
meet their needs due to long waiting times, inadequate consultation time, overcrowding, and high-occupancy bed rates [3]. This has resulted in the rapid expansion of a private health system, which was projected to grow from US $\$ 6.6$ billion in 2016 to US $\$ 8.7$ billion in 2020 [83]. Smart solutions that use big data, cloud computing, and mobile technology are strongly encouraged to alleviate overcrowded public hospitals and increase quality health care overall [4].

Together, all these supportive policy, social, technological, and economic environments provide a good foundation for the health care system in Vietnam to shift toward innovative models of care that are being proposed in developed countries, such as the BHS, which focus on patient-centered care.

\section{Threats}

In Vietnam, patient medical records remain paper-based at all levels of the health care system and currently are required for legal purposes [84]. Moreover, although electronic administration management has been adopted in some large hospitals, the quality of medical records and databases varies across hospitals and clinics. In most health care facilities, the medical record system is not centralized [52]. As such, one patient can have multiple medical records. This is a barrier for timely medical information exchange and sharing between hospitals [69]. In addition, the development of EMRs and EHRs, a precondition for BHS adoption, is still in the early stages [4,44]. Although $\mathrm{MOH}$ has taken initial steps toward the development of EMR and EHR systems, the readiness to implement the EMR nationally in real clinical practice still requires considerable preparatory effort.

First, Vietnam needs to assign a unique patient identifier to every citizen, which is a core requirement for successfully introducing EHRs [52]. In 2019, MOH issued Decision 4376/QĐ-BYT, regulating the establishment, use, and management of IDs [85]. According to the decision, an ID will be created, comprising two series of numbers separated by a dot. The first series is the social insurance code of the individual while the second series is a product of an algorithm of administrative information including the social insurance code, full name, date of birth, gender, and place of birth. The social insurance, however, is a compulsory income protection insurance for employed people only to fully or partially offset their income that is reduced or lost due to sickness, maternity, labor accident, occupational disease, retirement, or death [86]. Although Vietnam has made significant progress in expanding social insurance coverage in recent years, enrollment rates are still low, especially in small- and medium-size enterprises due to multiple barriers such as cost of contribution, lack of trust in the government system, and administrative factors [87]. Despite large increases in government subsidies, low enrollment rates in compulsory social and health insurance still persist [88]. In May 2020, only 27\% of Vietnam's workforce had social insurance $[89,90]$, which is far short of the government's target of 50\% social insurance coverage [87] and $80 \%$ health insurance coverage by 2020 [91,92]. The IDs, when established, therefore, will only cover a small proportion of the population.

Second, although many health workers and patients are aware of the advantages of using EMRs and EHRs, there are concerns about the risks of privacy violation. The Law on Network Information Security No. 86/2015/QH13, enacted in 2015, includes a requirement of "providing an adequate level of protection for personal data, following the technical standards for protection of personal data." However, there are no clear definitions of "an adequate level of protection" and "technical standards" [93]. As such, there is a lack of regulatory rigor and sanctions in managing data processors. Strengthening the legal and regulatory system to protect patient privacy and information security is fundamental for the success of EMR development and application.

Finally, since Vietnam is still in the very early stage of health care digitalization, there is no empirical evidence about the effectiveness and sustainability of digital health initiatives. Over the past few years, there have been a growing number of organizations and health startups delivering digital health solutions to improve the quality of medical services. For example, eHospital software, developed by the Corporation for Financing and Promoting Technology, was first launched in 2000 [94]. This is a comprehensive hospital management system providing supports to manage all activities relating to patients in health care facilities. In 2018, eHospital with the application of the latest 4.0 technologies such as artificial intelligence and big data was introduced. Until now, this system has been used in more than 400 hospitals and clinics in Vietnam. [95].

Another example is the Hospital Information System of the Vietnam Posts and Telecommunications Group, which was introduced in 2015. This solution with its three levels of management — state, hospital and patient-aims at supporting provincial health authorities and hospital managers to make well-informed decisions for health care improvement and assisting patients to facilitate and adhere to their health care appointments online. This allegedly leads to increasing transparency and reducing overcrowding in health care facilities [96]. Nevertheless, these initiatives have not been rigorously evaluated. Lack of evaluation results will prevent the government from evidence-based policymaking and hinder the broader implementation of existing projects or development of new initiatives.

\section{Discussion}

\section{Necessary Conditions for Successful Adoption of the BHS Model in Vietnam}

Vietnam has identifiable opportunities to adopt the BHS model and implement digitalization in health care. To grasp these opportunities, the following strategies are recommended.

First, establishing a national ID for each individual based on their social insurance code is one core requirement for successfully introducing EHRs. In a recent Organisation for Economic Co-operation and Development policy report, recommendations have been proposed for the Vietnamese government to increase the enrollment rates of social insurance. They include reducing obstacles to participation (eg, simplifying administration processes for paying insurance), introducing incentive scheme for employees to participate (eg, providing government subsidies for participation of low-income people 
in the voluntary system), and adopting a systematic approach to social protection (eg, considering the interaction between various social protection mechanisms) [87].

Second, successful adoption of the BHS requires a whole-system approach involving the support of different sectors in the society. Obviously, $\mathrm{MOH}$ would have to play a key role in this adoption process but would need to collaborate with related ministries-in particular, the Ministry of Science and Technology and the Ministry of Information and Communications-in developing and implementing a digital health strategy. The resources needed to improve the health care system are sizeable. $\mathrm{MOH}$ would need to garner funding from different sources, both domestic and foreign agencies: government, social entrepreneurs, or private businesses $[69,70]$.

Third, integrating personal data in EHR and EMR systems will increase the risk of privacy violation and cybersecurity breaches. The Vietnamese government needs to improve the security of information technology platforms in general and health care in particular to protect patient privacy and information security [70].

Fourth, to improve the adoption of evidence-based practices, it will be necessary to provide resources to demonstrate the effectiveness and impact of digital health initiatives and establish a network of collaborators including health care administrators, clinicians, community representatives, digital health researchers, information technology developers, and public health education experts [69]. This will be a great opportunity for further enhancing strong collaborations between multisectors and multistakeholders at various levels, which are essential for successfully reforming the health care system in Vietnam. BHS implementation would require the involvement of local educators to provide education for communities, raising awareness of the benefits the system could bring to individuals and society, coaching to enhance self-management behaviors, and increasing engagement with the system [97]. Strong evidence about the effectiveness of digital health initiatives in Vietnam will encourage the government to develop appropriate health policies and increase opportunities for ongoing projects to scale-up by attracting funding and support [70]. Thus, there is a substantial need for further research in this area in the future.

Finally, to increase the acceptability and feasibility of digital health initiatives, a co-design approach is crucial. Co-design is defined as the "collective creativity as it is applied across the whole span of a design process" [98]. In the design process, diverse experts such as researchers, designers or developers and potential customers and users work closely together to understand the needs and preferences of end users [99,100]. A co-design approach is likely to increase scalability and dissemination of the initiative [99].

\section{Conclusions}

The overarching goal of the BHS is, with the support of digital technologies, to deliver best practice health care and reduce pressure on the current health care system by empowering people to direct their own health care, regardless of their geographical location and economic status [44]. The BHS offers a promising and intelligent health care that which may be efficient and suitable for Vietnam in the new era of the Fourth Industrial Revolution [101]. Vietnam has tremendous opportunities and a favorable policy, social, technological, and economic environment to adopt this model of comprehensive patient-centric health care. In order to uptake, adapt, and implement the BHS successfully, Vietnam needs to apply a whole-system approach in transformation and operation processes.

\section{Acknowledgments}

We thank Dr Hilary Schofield for her proofreading and thorough editing.

\section{Conflicts of Interest}

None declared.

\section{References}

1. The World Bank in Vietnam. Hanoi: The World Bank; 2019. URL: https://www.worldbank.org/en/country/vietnam/overview [accessed 2020-05-24]

2. The World Bank indicators. Washington: World Bank; 2020. URL: https://data.worldbank.org/indicator/ [accessed 2020-08-16]

3. Digital health in Vietnam: a guide to market. Australian Trade and Investment Commission. 2019. URL: https://www. austrade.gov.au/ArticleDocuments/4569/Digital\%20Health\%20in\%20Vietnam\%20Report.pdf.aspx [accessed 2021-05-23]

4. Plan for people's health protection, care and promotion 2016-2020. Hanoi: Ministry of Health of Vietnam; 2016. URL: http://faolex.fao.org/docs/pdf/vie179587.pdf [accessed 2021-05-23]

5. World population prospects: the 2015 revision. Department of Economic and Social Affairs, Population Division, United Nations. 2015 Jun 12. URL: https://esa.un.org/unpd/wpp/Publications/Files/Key Findings WPP 201pdf [accessed 2020-05-24]

6. Statistical yearbook of Vietnam 2018. Hanoi: General Statistics of Vietnam; 2019. URL: https://www.gso.gov.vn/wp-content/ uploads/2019/10/Nien-giam-2018-1.pdf [accessed 2021-05-24] 
7. Monitoring the building blocks of health systems: a handbook of indicators and their measurement strategies. Geneva: World Health Organization; 2010. URL: https://www.who.int/healthinfo/systems/WHO MBHSS 2010 full web.pdf?ua=1 [accessed 2021-05-24]

8. Boerma T, Abou - Zahr C, Bos E, Hansen P, Addai E, Low - Beer D. Monitoring and evaluation of health systems strengthening: an operational framework. Geneva: World Health Organization; 2009. URL: https://www.who.int/healthinfo/ HSS MandE framework Nov 2009.pdf [accessed 2021-05-24]

9. Hoang VM, Oh J, Tran TA, Tran TGH, Ha AD, Luu NH, et al. Patterns of health expenditures and financial protections in Vietnam 1992-2012. J Korean Med Sci 2015 Nov;30 Suppl 2:S134-S138 [FREE Full text] [doi: 10.3346/jkms.2015.30.S2.S134] [Medline: 26617446]

10. Ministry of Health of Vietnam and Department of Planning and Finance. National health account: implemented in Vietnam period 1998-2012. Hanoi: Statistical Publishing House; 2014.

11. Health financing strategy in Asia-Pacific region (2010-2015). Geneva: World Health Organization; 2009. URL: https:/ lapps.who.int/iris/bitstream/handle/10665/207746/9789290614586_eng.pdf?sequence=1\&isAllowed=y [accessed 2021-05-24]

12. Health financing in Vietnam. Geneva: World Health Organization URL: https://www.who.int/vietnam/health-topics/ health-financing [accessed 2020-08-22]

13. The Prime Minister of Vietnam. Decision of the Prime Minister No. 139/2002/QD-TTG on examination and treatment of poverty people. Hanoi: Legal library; 2002. URL: https://thuvienphapluat.vn/van-ban/the-thao-y-te/ Quyet-dinh-139-2002-QD-TTg-kham-chua-benh-cho-nguoi-ngheo-50086.aspx [accessed 2020-08-22]

14. Xu K, Evans DB, Kawabata K, Zeramdini R, Klavus J, Murray CJL. Household catastrophic health expenditure: a multicountry analysis. Lancet 2003 Jul 12;362(9378):111-117. [doi: 10.1016/S0140-6736(03)13861-5] [Medline: 12867110]

15. van Doorslaer E, O'Donnell O, Rannan-Eliya RP, Somanathan A, Adhikari SR, Garg CC, et al. Effect of payments for health care on poverty estimates in 11 countries in Asia: an analysis of household survey data. Lancet 2006 Oct 14;368(9544):1357-1364. [doi: 10.1016/S0140-6736(06)69560-3] [Medline: 17046468]

16. Anand S, Bärnighausen T. Health workers and vaccination coverage in developing countries: an econometric analysis. Lancet 2007 Apr 14;369(9569):1277-1285. [doi: 10.1016/S0140-6736(07)60599-6] [Medline: 17434403]

17. Speybroeck N. Reassessing the relationship between human resources for health, intervention coverage and health outcomes: the world health report 2006. Geneva: World Health Organization; 2006. URL: https://www.who.int/hrh/documents/ reassessing_relationship.pdf [accessed 2021-05-24]

18. Krakauer EL, Cham NTP, Khue LN. Vietnam's palliative care initiative: successes and challenges in the first five years. J Pain Symptom Manage 2010 Jul;40(1):27-30 [FREE Full text] [doi: 10.1016/j.jpainsymman.2010.04.009] [Medline: 20619210]

19. Health at a glance Asia/Pacific 2016. Organisation for Economic Co-operation and Development. 2016. URL: $\underline{\text { https://www. }}$ oecd-ilibrary.org/health-at-a-glance-asia-pacific-2016 5jlsgjk4ktxs. pdf?itemId=\%2Fcontent $\% 2$ Fpublication \%2Fhealth_glance_ap-2016-en\&mimeType=pdf [accessed 2021-05-24]

20. Vuong DA, Van Ginneken E, Morris J, Ha ST, Busse R. Mental health in Vietnam: burden of disease and availability of services. Asian J Psychiatr 2011 Mar;4(1):65-70. [doi: 10.1016/j.ajp.2011.01.005] [Medline: 23050918]

21. Nguyen HTT, Kitaoka K, Sukigara M, Thai AL. Burnout study of clinical nurses in Vietnam: development of job burnout model based on Leiter and Maslach's Theory. Asian Nurs Res (Korean Soc Nurs Sci) 2018 Mar;12(1):42-49 [FREE Full text] [doi: 10.1016/j.anr.2018.01.003] [Medline: 29463486]

22. Shanafelt T, Dyrbye L. Oncologist burnout: causes, consequences, and responses. J Clin Oncol 2012 Apr 10;30(11):1235-1241. [doi: 10.1200/JCO.2011.39.7380] [Medline: 22412138]

23. Circular 19/2013/TT-BYT: Specifying implementation guidelines for healthcare service quality management in hospitals. Hanoi: Ministry of Health of Vietnam; 2013. URL: https://vanbanphapluat.co/ circular-19-2013-tt-byt-implementation-guidelines-healthcare-service-quality-management-hospitals [accessed 2021-05-24]

24. Bentley TGK, Effros RM, Palar K, Keeler EB. Waste in the U.S. health care system: a conceptual framework. Milbank Q 2008 Dec;86(4):629-659 [FREE Full text] [doi: 10.1111/j.1468-0009.2008.00537.x] [Medline: 19120983]

25. Nguyen TKT, Cheng T. Vietnam's health care system emphasizes prevention and pursues universal coverage. Health Aff (Millwood) 2014 Nov;33(11):2057-2063. [doi: 10.1377/hlthaff.2014.1141] [Medline: 25354953]

26. Le D, Kubo T, Fujino Y, Pham T, Matsuda S. Health care system in Vietnam: current situation and challenges. Asian Pac J Dis Manag 2010;4(2):23-30. [doi: 10.7223/apjdm.4.23]

27. Nguyen H, Nguyen T, van den Heuvel ER, Haaijer-Ruskamp FM, Taxis K. Medication errors in Vietnamese hospitals: prevalence, potential outcome and associated factors. PLoS One 2015;10(9):e0138284 [FREE Full text] [doi: 10.1371/journal.pone.0138284] [Medline: 26383873]

28. Demombynes G, Hurt K. Quality and equity in basic health care services in Vietnam: findings from the Vietnam District and Commune Health Facility Survey. Washington: World Bank; 2015. URL: https://microdata.worldbank.org/index.php/ catalog/2728/download/39045 [accessed 2021-05-24]

29. Falkenberg T, Nguyen TB, Larsson M, Nguyen TD, Tomson G. Pharmaceutical sector in transition-a cross sectional study in Vietnam. Southeast Asian J Trop Med Public Health 2000 Sep;31(3):590-597. [Medline: 11289028] 
30. Aït-Khaled N, Auregan G, Bencharif N, Camara LM, Dagli E, Djankine K, et al. Affordability of inhaled corticosteroids as a potential barrier to treatment of asthma in some developing countries. Int J Tuberc Lung Dis 2000 Mar;4(3):268-271. [Medline: 10751075$]$

31. Nguyen A, Knight R, Mant A, Cao M, Auton M. Medicine prices, availability, and affordability in Vietnam. Southern Med Review 2009;2(2):2-9 [FREE Full text] [doi: 10.1016/b978-0-12-813166-4.00012-7]

32. Nguyen T. Medicine Prices and Pricing Policies in Vietnam [Thesis]. Sydney: UNSWorks; 2011.

33. Nguyen T, Vitry A, Roughead E. Pharmaceutical policy in Vietnam. In: Babar Z, editor. Pharmaceutical Policy in Countries with Developing Healthcare Systems. 1st Edition. Cham: Springer International Publishing; 2017:75-94.

34. Nguyen T, Roughead E. Pharmaceutical pricing policies in Vietnam. In: Pharmaceutical Prices in the 21st Century. 1st Edition. Cham: Springer International Publishing; 2015:321-342.

35. Nguyen T, Knight R, Mant A, Razee H, Brooks G, Dang T. Inflated medicine prices in Vietnam: a qualitative study. Health Policy Plann Jun 2017;32(5):647-656. [doi: 10.1093/heapol/czw174] [Medline: 28160482]

36. Nguyen TA, Knight R, Mant A, Razee H, Brooks G, Dang TH, et al. Corruption practices in drug prescribing in Vietnam: an analysis based on qualitative interviews. BMC Health Serv Res 2018 Jul 28;18(1):587 [FREE Full text] [doi: 10.1186/s12913-018-3384-3] [Medline: $\underline{\text { 30055601] }}$

37. Wang H, Sun Q, Vitry A, Nguyen TA. Availability, price, and affordability of selected essential medicines for chronic diseases in 11 countries of the Asia Pacific Region: a secondary analysis. Asia Pac J Public Health 2017 May;29(4):268-277. [doi: 10.1177/1010539517700472] [Medline: 28397532]

38. The Congress of Vietnam. Heath insurance law. Hanoi: Legal library; 2014. URL: https://thuvienphapluat.vn/van-ban/ Bao-hiem/Luat-Bao-hiem-y-te-sua-doi-2014-238506.aspx [accessed 2020-08-23]

39. The Congress of Vietnam. Pharmaceutical law. Hanoi: Legal library; 2016. URL: https://thuvienphapluat.vn/van-ban/ The-thao-Y-te/Luat-Duoc-2016-309815.aspx [accessed 2020-08-23]

40. The Prime Minister of Vietnam. Health sector strategy for 2011-2020 with a vision to 2030. Hanoi: Legal library; 2013. URL: http://www.chinhphu.vn/portal/page/portal/chinhphu/hethongvanban?class id=2\&mode=detail\&document id=165437 [accessed 2020-09-23]

41. Kay M, Santos J, Takane M. mHealth: New Horizons for Health Through Mobile Technologies. Geneva: World Health Organization; 2011.

42. Digital health. Geneva: World Health Organization; 2020. URL: https://www.who.int/health-topics/digital-health\#tab=tab_1 [accessed 2020-08-23]

43. Reynolds A. Patient-centered care. Radiol Technol 2009;81(2):133-147. [Medline: 19901351]

44. Schofield P, Shaw T, Pascoe M. Toward comprehensive patient-centric care by integrating digital health technology with direct clinical contact in Australia. J Med Internet Res 2019 Jun 04;21(6):e12382 [FREE Full text] [doi: 10.2196/12382] [Medline: $\underline{31165713}$ ]

45. Bergmann J, Sams A. Flip Your Classrom: Reach Every Student in Every Class Every Day. Washington: International Society for Technology in Education; 2019.

46. Lage MJ, Platt GJ, Treglia M. Inverting the classroom: a gateway to creating an inclusive learning environment. J Econ Educ 2000;31(1):30. [doi: 10.2307/1183338]

47. Mate KS, Salinas G. Flipping primary health care: a personal story. Healthc (Amst) 2014 Dec;2(4):280-283. [doi: 10.1016/j.hjdsi.2014.10.003] [Medline: 26250637]

48. Roughhead L, Semple S, Rosenfeld E. Literature review: medication safety in Australia. Sydney: Australian Commission on Safety and Quality in Health Care; 2013. URL: https://www.safetyandquality.gov.au/sites/default/files/migrated/ Literature-Review-Medication-Safety-in-Australia-2013.pdf [accessed 2021-05-27]

49. Alkhaldi G, Hamilton FL, Lau R, Webster R, Michie S, Murray E. The effectiveness of prompts to promote engagement with digital interventions: a systematic review. J Med Internet Res 2016;18(1):e6 [FREE Full text] [doi: 10.2196/jmir.4790] [Medline: 26747176]

50. Circular promolgating the criteria of application of information technology application at medical examination and treatment establishments. Hanoi: Ministry of Health of Vietnam; 2017. URL: https://vanbanphapluat.co/ circular-54-2017-tt-byt-assessment-of-information-technology-application-at-health-facilities [accessed 2021-05-24]

51. Schaller S, Marinova-Schmidt V, Setzer M, Kondylakis H, Griebel L, Sedlmayr M, et al. Usefulness of a tailored ehealth service for informal caregivers and professionals in the dementia treatment and care setting: the ehealth monitor dementia portal. JMIR Res Protoc 2016 Apr 05;5(2):e47 [FREE Full text] [doi: 10.2196/resprot.4354] [Medline: 27050401]

52. Hochwarter S, Do D, Nguyen T, Larsson M. Towards an electronic health record system in Vietnam: a core readiness assessment. J Health Inform Devel Countr 2014;8(2):1 [FREE Full text]

53. Vietnamese Party's Central Committee. Resolution 20-NQ/TW. Hanoi: Law library of Vietnam; 2017. URL: https:/ /thuvienphapluat.vn/van-ban/the-thao-y-te/

Nghi-quyet-20-NQ-TW-2017-tang-cuong-cong-tac-bao-ve-cham-soc-nang-cao-suc-khoe-nhan-dan-365599.aspx [accessed 2021-06-03]

54. Electronic Health Administration. Smart health development in the period of 2019-2025, vision to 2030. Hanoi: Ministry of Health of Vietnam; 2019. URL: https://ehealth.gov.vn/?action=News\&newsId=47145 [accessed 2021-06-07] 
55. Ministry of Health of Vietnam. Circular regulations on telemedicine activities. Hanoi: Legal library; 2017. URL: https:/ /thuvienphapluat.vn/van-ban/The-thao-Y-te/Circular-49-2017-TT-BYT-on-telemedicine-374119.aspx [accessed 2020-06-07]

56. Häyrinen K, Saranto K, Nykänen P. Definition, structure, content, use and impacts of electronic health records: a review of the research literature. Int J Med Inform 2008 May;77(5):291-304. [doi: 10.1016/j.ijmedinf.2007.09.001] [Medline: 17951106]

57. Electronic Health Administration. Circular No. 46/2018/TT-BYT regulating electronic medical records. Hanoi: Ministry of Health of Vietnam; 2018. URL: https://ehealth.gov.vn/Index.aspx?action=GioiThieu\&MenuChildID=391\&Id=4262 [accessed 2020-06-13]

58. Hospitals in Vietnam. Geneva: World Health Organization; 2020. URL: https://www.who.int/vietnam/health-topics/hospitals [accessed 2020-06-08]

59. Plan for implementing Electronic Health Records. Hanoi: Ministry of Health of Vietnam; 2019. URL: https://thuvienphapluat. vn/van-ban/the-thao-y-te/Quyet-dinh-5349-QD-BYT-2019-phe-duyet-Ke-hoach-trien-khai-ho-so-suc-khoe-dien-tu-428071. aspx [accessed 2020-06-13]

60. Doan EZ. Vietnam: number of Facebook users 2017-2023. Statista. 2020. URL: https://www.statista.com/statistics/553800/ facebook-penetration-in-vietnam/ [accessed 2020-06-08]

61. Vietnamese people spend much of their time online. Hanoi: Vietnam News; 2018. URL: https://vietnamnews.vn/economy/ 481777/vietnamese-people-spend-much-of-their-time-online.html\#: :text=The\%20figures $\% 20$ released $\% 20 \mathrm{by} \% 20$ the,of $\% 203$. 55\%20hours\%20per\%20day [accessed 2021-05-26]

62. Do TTT, Le MD, Van Nguyen T, Tran BX, Le HT, Nguyen HD, et al. Receptiveness and preferences of health-related smartphone applications among Vietnamese youth and young adults. BMC Public Health 2018 Jun 19;18(1):764 [FREE Full text] [doi: 10.1186/s12889-018-5641-0] [Medline: 29921258]

63. Tran BX, Zhang MW, Le HT, Nguyen HD, Nguyen LH, Nguyen QLT, et al. What drives young Vietnamese to use mobile health innovations? Implications for health communication and behavioral interventions. JMIR Mhealth Uhealth 2018 Nov 30;6(11):e194 [FREE Full text] [doi: 10.2196/mhealth.6490] [Medline: 30251704]

64. Individuals using the internet (\% of population)_Vietnam. World Bank. 2021. URL: https://data.worldbank.org/indicator/ IT.NET.USER.ZS?locations=VN [accessed 2021-05-31]

65. Vu LTH, Nguyen NTK, Tran HTD, Muhajarine N. mHealth information for migrants: an e-health intervention for internal migrants in Vietnam. Reprod Health 2016 May 14;13(1):55 [FREE Full text] [doi: 10.1186/s12978-016-0172-6] [Medline: 27180147]

66. Ngan TT, Do VV, Huang J, Redmon PB, Minh HV. Willingness to use and pay for smoking cessation service via text-messaging among Vietnamese adult smokers, 2017. J Subst Abuse Treat 2019 Sep;104:1-6. [doi: 10.1016/j.jsat.2019.05.014] [Medline: 31370973 ]

67. Tran BX, Le XTT, Nguyen PN, Le QNH, Mai HT, Nguyen HLT, et al. Feasibility of e-Health interventions on smoking cessation among Vietnamese active internet users. Int J Environ Res Public Health 2018 Dec 20;15(1):1 [FREE Full text] [doi: 10.3390/ijerph15010165] [Medline: 29361694]

68. Bates LA, Hicks JP, Walley J, Robinson E. Evaluating the impact of Marie Stopes International's digital family planning counselling application on the uptake of long-acting and permanent methods of contraception in Vietnam and Ethiopia: a study protocol for a multi-country cluster randomised controlled trial. Trials 2018 Aug 04;19(1):420 [FREE Full text] [doi: 10.1186/s13063-018-2815-0] [Medline: 30075739]

69. Nguyen QT, Naguib RNG, Abd Ghani MK, Bali RK, Lee IM. An analysis of the healthcare informatics and systems in Southeast Asia: a current perspective from seven countries. Int J Electron Healthc 2008;4(2):184-207. [doi: 10.1504/IJEH.2008.019792] [Medline: 18676343 ]

70. Lam JA, Dang LT, Phan NT, Trinh HT, Vu NC, Nguyen CK. Mobile health initiatives in Vietnam: scoping study. JMIR Mhealth Uhealth 2018 Apr 24;6(4):e106 [FREE Full text] [doi: 10.2196/mhealth.8639] [Medline: 29691214]

71. McBride B, Nguyen LT, Wiljer D, Vu NC, Nguyen CK, O'Neil J. Development of a maternal, newborn and child mHealth intervention in Thai Nguyen province, Vietnam: protocol for the mMom Project. JMIR Res Protoc 2018 Jan 11;7(1):e6 [FREE Full text] [doi: 10.2196/resprot.7912] [Medline: 29326095]

72. McBride B, O'Neil JD, Hue TT, Eni R, Nguyen CV, Nguyen LT. Improving health equity for ethnic minority women in Thai Nguyen, Vietnam: qualitative results from an mHealth intervention targeting maternal and infant health service access. J Public Health (Oxf) 2018 Dec 01;40(suppl_2):ii32-ii41 [FREE Full text] [doi: 10.1093/pubmed/fdy165] [Medline: $\underline{30252117]}$

73. Sabin LL, Larson WA, Le BN, Herman AR, Viet NH, Albanese RR, et al. Benefits and limitations of text messages to stimulate higher learning among community providers: participants' views of an mHealth intervention to support continuing medical education in Vietnam. Glob Health Sci Pract 2017 Jun 27;5(2):261-273 [FREE Full text] [doi: 10.9745/GHSP-D-16-00348] [Medline: 28655802]

74. Larson Williams A, Hawkins A, Sabin L, Halim N, Le Ngoc B, Nguyen VH, et al. Motivating HIV providers in Vietnam to learn: a mixed-methods analysis of a mobile health continuing medical education intervention. JMIR Med Educ 2019 Apr 18;5(1):e12058 [FREE Full text] [doi: 10.2196/12058] [Medline: 30998220] 
75. Gill CJ, Le NB, Halim N, Chi CTH, Nguyen VH, Bonawitz R, et al. mCME project V.2.0: randomised controlled trial of a revised SMS-based continuing medical education intervention among HIV clinicians in Vietnam. BMJ Glob Health 2018;3(1):e000632 [FREE Full text] [doi: 10.1136/bmjgh-2017-000632] [Medline: 29527350]

76. Bonawitz R, Bird L, Le NB, Nguyen VH, Halim N, Williams AL, et al. Implementing the mobile continuing medical education (mCME) project in Vietnam: making it work and sharing lessons learned. Mhealth 2019;5:7 [FREE Full text] [doi: 10.21037/mhealth.2019.02.01] [Medline: 30976599]

77. Pollack TM, Nhung VTT, Vinh DTN, Hao DT, Trang LTT, Duc PA, et al. Building HIV healthcare worker capacity through telehealth in Vietnam. BMJ Glob Health 2020;5(4):e002166 [FREE Full text] [doi: 10.1136/bmjgh-2019-002166] [Medline: 32337087]

78. Davis MC, Can DD, Pindrik J, Rocque BG, Johnston JM. Virtual interactive presence in global surgical education: international collaboration through augmented reality. World Neurosurg 2016 Mar;86:103-111 [FREE Full text] [doi: 10.1016/j.wneu.2015.08.053] [Medline: 26342783]

79. Hersh D, Hersch F, Mikuletic L, Neilson S. A Web-based approach to low-cost telemedicine. J Telemed Telecare 2003;9 Suppl 2:S24-S26. [doi: 10.1258/135763303322596174] [Medline: 14728752]

80. Imamura K, Tran TTT, Nguyen HT, Kuribayashi K, Sakuraya A, Nguyen AQ, et al. Effects of two types of smartphone-based stress management programmes on depressive and anxiety symptoms among hospital nurses in Vietnam: a protocol for three-arm randomised controlled trial. BMJ Open 2019 Apr 08;9(4):e025138 [FREE Full text] [doi:

10.1136/bmjopen-2018-025138] [Medline: 30962230]

81. GDP growth (annual \%)_Vietnam. Washington: World Bank; 2020. URL: https://data.worldbank.org/indicator/NY.GDP. MKTP.KD.ZG?locations=VN [accessed 2020-06-08]

82. Vietnam 2035: toward prosperity, creativity, equity and democracy. Washington: World Bank; 2016. URL: https:/ lopenknowledge.worldbank.org/bitstream/handle/10986/23724/9781464808241.pdf?sequence=12\&isAllowed=y [accessed 2021-05-24]

83. Das K. Vietnam: growing demand for healthcare services. Hanoi: Vietnam Briefing; 2018 Sep 14. URL: https://www. vietnam-briefing.com/news/vietnam-growing-demand-healthcare-services.html/ ?hilite $=\% 27$ Growing $\% 27 \% 2 \mathrm{C} \% 27$ Demand $\% 27 \% 2 \mathrm{C} \% 27 \mathrm{Healthcare} \% 27 \% 2 \mathrm{C} \% 27$ Services $\% 27$ [accessed 2020-06-08]

84. The Congress of Vietnam. The law of disease examination and treatment. Hanoi: Government of the Socialist Republic of Vietnam; 2009. URL: http://vanban.chinhphu.vn/portal/page/portal/chinhphu/ hethongvanban?class $\mathrm{id}=1 \&$ page $=1 \&$ mode=detail\&document id=92348 [accessed 2020-07-25]

85. Electronic Health Administration. Decision 4376/QĐ-BYT, promulgating the regulation on the establishment, use and management of health identifications. Hanoi: Ministry of Health of Vietnam; 2019. URL: https://ehealth.gov.vn/Index. aspx ?action=Detail \&MenuChildID=\&Id=4372 [accessed 2020-06-13]

86. The Congress of Vietnam. Social insurance Law. Hanoi: Law library; 2014. URL: https://huvienphapluat.vn/van-ban/ bao-hiem/Luat-Bao-hiem-xa-hoi-2014-259700.aspx [accessed 2020-07-25]

87. Castel P, Pick A. Increasing social insurance coverage in Viet Nam's SMEs. OECD. 2018. URL: https://www.oecd.org/ dev/inclusivesocietiesanddevelopment/Increasing social insurance coverage in Vietnam SMES.pdf [accessed 2021-05-24]

88. Somanathan AT, Dao H, Hurt K, Fuenzalida-Puelma H. Moving toward universal coverage of social health insurance in Vietnam-assessment and options. Washington: World Bank; 2014. URL: http://documents1.worldbank.org/curated/en/ 383151468138892428/pdf/Moving-toward-universal-coverage-of-social-health-insurance-in-Vietnam-assessment-and-options. pdf [accessed 2021-05-24]

89. Press release on labor and employment situation in the first quarter of 2019. Hanoi: General Statistics Office of Vietnam; 2019. URL: https://www.gso.gov.vn/en/employment/ [accessed 2021-05-26]

90. Thoa D. The number of people participating in compulsory social insurance decreases and voluntary social insurance increases. Hanoi: Vietnam Communist Party electronic newspaper; 2020. URL: http://dangcongsan.vn/ bao-hiem-xa-hoi-bao-hiem-y-te-vi-an-sinh-xa-hoi/tin-tucl so-nguoi-tham-gia-bao-hiem-xa-hoi-bat-buoc-giam-bao-hiem-xa-hoi-tu-nguyen-tang-556718.html [accessed 2020-07-26]

91. Prime Minister of Vietnam. Decision 538/QD-TTg: Approving the project on implementation of program to comprehensive health insurance period 2012-2015 and toward 2020. Hanoi: Legal library; 2013. URL: https://thuvienphapluat.vn/van-ban/ bao-hiem/quyet-dinh-538-qd-ttg-nam-2013-phe-duyet-de-an-thuc-hien-lo-trinh-bhyt-toan-dan-179586.aspx [accessed 2020-06-08]

92. Takashima K, Wada K, Tra TT, Smith DR. A review of Vietnam's healthcare reform through the Direction of Healthcare Activities (DOHA). Environ Health Prev Med 2017 Oct 30;22(1):74 [FREE Full text] [doi: 10.1186/s12199-017-0682-z] [Medline: 29165160]

93. National Assembly of Vietnam. Law on network information security No. 86/2015/QH13. Hanoi: Legislation web portal; 2015. URL: https://vanbanphapluat.co/law-no-86-2015-qh13-on-cyberinformation-security-2015 [accessed 2020-06-08]

94. Do N. MoH partners with FPT to build smart medical model. Hanoi: Vietnam Economic Times; 2018 Aug 16. URL: http:/ /vneconomictimes.com/article/society/moh-partners-with-fpt-to-build-smart-medical-model [accessed 2020-07-27]

95. FPT launches hospital management solution applying 4.0 technology. FPT. 2018. URL: https://fpt.com.vn/en/ir/featured-news/ fpt-launches-hospital-management-solution-applying-4-0-technology [accessed 2020-07-27] 
96. Tuyet M. VNPT introduces solution to improving healthcare. Hanoi: Vietnam Economics Times; 2015 Jun 26. URL: http:/ /www.vneconomictimes.com/article/business/vnpt-introduces-solution-to-improving-healthcare [accessed 2020-07-27]

97. Schneider H, Hill S, Blandford A. Patients know best: qualitative study on how families use patient-controlled personal health records. J Med Internet Res 2016 Feb 24;18(2):e43 [FREE Full text] [doi: 10.2196/jmir.4652] [Medline: 26912201]

98. Sanders EB, Stappers PJ. Co-creation and the new landscapes of design. CoDesign 2008 Mar;4(1):5-18. [doi: $\underline{10.1080 / 15710880701875068]}$

99. Bate P, Robert G. Bringing User Experience to Healthcare Improvement: The Concepts, Methods and Practices of Experience-based Design. Oxford: Radcliffe Publishing; 2007.

100. Steen M, Manschot M, de Koning KN. Benefits of co-design in service design projects. Int J Des. 2: 5; 2011. URL: http:/ /www.ijdesign.org/index.php/IJDesign/article/view/890/346 [accessed 2021-05-24]

101. Fourth industrial revolution. World Economic Forum. 2020. URL: https://www.weforum.org/focus/fourth-industrial-revolution [accessed 2020-06-14]

\author{
Abbreviations \\ BHS: Bespoke Health Care System \\ EHR: electronic health record \\ EMR: electronic medical record \\ HIS: health information system \\ MOH: Ministry of Health of Vietnam \\ NCD: noncommunicable disease \\ OPP: out-of-pocket payment \\ SWOT: strength, weakness, opportunity, and threat analysis \\ THE: total health expenditure \\ WHO: World Health Organization
}

\author{
Edited by $G$ Eysenbach; submitted 27.09.20; peer-reviewed by D Adriaans, $N$ Phan; comments to author 05.11.20; revised version \\ received 29.12.20; accepted 14.04.21; published 04.06.21 \\ Please cite as: \\ Dang TH, Nguyen TA, Hoang Van M, Santin O, Tran OMT, Schofield P \\ Patient-Centered Care: Transforming the Health Care System in Vietnam With Support of Digital Health Technology \\ J Med Internet Res 2021;23(6):e24601 \\ URL: https://www.jmir.org/2021/6/e24601 \\ doi: $10.2196 / 24601$ \\ PMID:
}

(C)Thu Ha Dang, Tuan Anh Nguyen, Minh Hoang Van, Olinda Santin, Oanh Mai Thi Tran, Penelope Schofield. Originally published in the Journal of Medical Internet Research (https://www.jmir.org), 04.06.2021. This is an open-access article distributed under the terms of the Creative Commons Attribution License (https://creativecommons.org/licenses/by/4.0/), which permits unrestricted use, distribution, and reproduction in any medium, provided the original work, first published in the Journal of Medical Internet Research, is properly cited. The complete bibliographic information, a link to the original publication on https://www.jmir.org/, as well as this copyright and license information must be included. 